\title{
Transcendendo o enfoque de gênero no contexto da violência no casal
}

\author{
Ana Claudia Nunes de Souza Wanderbroocke \\ Carmen Leontina Ojeda Ocampo More \\ Universidade Federal de Santa Catarina, Florianópolis-SC, Brasil
}

Cantera, L. M. (2007). Casais e violência: Um enfoque além do gênero. Porto Alegre: Dom Quixote.

A autora do livro em questão é Doutora em Psicologia Social pela Universidade Autônoma de Barcelona, pesquisadora com ênfase nos estudos sobre violência, gênero e trabalho e também leciona e coordena cursos sobre violência na família e no casal nessa instituição. Tem uma expressiva produção científica, na qual se observa uma perspectiva de desconstrução de saberes instituídos entorno da temática.

O livro é dividido em duas partes, sendo que na primeira a autora descreve o que atualmente é conhecido sobre violência no casal heterossexual, apoiando-se na perspectiva de gênero como um "paradigma herdado", conceito inspirado nas idéias de Stephen Toulmin, filósofo inglês, que sustentou a teoria da argumentação em livro publicado em 1963. Para contextualizar o conhecimento, recorre à metáfora teatral descrevendo o cenário (o patriarcado), o guia (os conceitos de sexo e gênero), os protagonistas (a vítima feminina e o agressor masculino) e o público ou espectadores (a ciência, o feminismo e a mídia).

$\mathrm{Na}$ segunda parte do livro, a autora lança-se em busca de um novo paradigma para a compreensão da violência no casal, não mais restrita à violência em casais heterossexuais. Procura dados para a elaboração de um modelo de compreensão da violência que ocorre tanto em casais homossexuais como em casais heterossexuais, que possibilite o empoderamento e facilite a saída das "vítimas" das situações de maustratos. Essa busca se dá por meio de uma pesquisa de campo e análises da literatura pertinente.

Leonor Cantera analisa o patriarcado, apresentando-o como modo de organização sócio-cultural androcêntrica e masculinista, que estrutura a totalidade das relações sociais e o modo de perceber, construir e administrar a realidade em termos de uma divisão precisa de papéis masculinos e femininos. De acordo com a autora, nesse sistema prepondera a assimetria e a desigualdade devido à hierarquia implícita que ordena verticalmente e disciplina, sempre sob a perspectiva do homem, que detém a primazia sobre a mulher - eixo central da cultura patriarcal. Com base nessa crença, há a

\footnotetext{
1 Endereço para correspondência:

Ana Claudia Nunes de Souza Wanderbroocke. Rua Paschoal Bordignon,

27. CEP 80.210-110. Curitiba-PR, Brasil. E-mail: anawdb@gmail.com
}

determinação das regras do jogo da violência que são aceitas, toleradas ou até mesmo necessárias para a manutenção do patriarcado.

Os maus-tratos no casal fazem parte das estratégias de dominação da mulher pelo homem, personagem socialmente reconhecido e legitimado como o sexo forte, detentor do poder nas relações conjugais. $\mathrm{O}$ que guia e possibilita a naturalização dos maus-tratos no casal, segundo a autora, é a compreensão da violência como derivada das relações entre macho e fêmea. A noção de sexo atrelado a atributos biológicos associa a masculinidade à função macho-caçador e a feminilidade à função reprodutora, derivando assim a divisão sexual do trabalho que confere aos homens as tarefas produtivas e às mulheres as reprodutivas, dando maior poder aos primeiros.

Seguindo a análise, a autora expõe as idéias associadas ao paradigma gênero-cultural, conforme introduzido pelo discurso feminista, no qual masculinidade e feminilidade não são consideradas como traços psicológicos derivados de atributos biológicos, mas como correspondência cultural do sexo, ou seja, construções sócio-culturais impostas aos homens e as mulheres. A perspectiva de gênero contribui para que a violência no casal seja entendida não mais como algo natural, derivado da natureza sexual das relações entre macho e fêmea, mas como um processo histórico-cultural, perpetuado pelas estruturas de dominação do patriarcado.

Continuando a análise do drama da violência no casal, a autora apresenta os personagens e o público. Entre os personagens, encontram-se o homem-vitimizador e a mulher-vitimizada, papéis clássicos construídos pela guia patriarcal por meio dos discursos social, jurídico e político. Geralmente os homens são os protagonistas de estudos que identificam as causas, os desencadeadores, as razões da violência e o perfil do agressor, e as mulheres protagonizam estudos sobre as consequências dos maus-tratos e perfil de vítima.

Entre os espectadores-participantes a autora inclui o feminismo, a ciência e a mídia. Aponta as inúmeras facetas do feminismo, destacando as posições antagônicas entre a corrente essencialista e a corrente clássica. A ciência com as vertentes naturalista, com ênfase na filogênese e fundamentação biológica da violência; a vertente culturalista, compreendendo a violência como sendo de determinação social 
e cultural; e a vertente interacionista, apresentando o jogo entre natureza e cultura. Por fim, a mídia, que por um lado contribui dando visibilidade à questão, ao mesmo tempo em que distorce e banaliza o tema.

Argumenta que o feminismo, por meio do ativismo em prol das mulheres, impulsionou os estudos e deu visibilidade para a violência no casal. Porém, o "efeito colateral" dessa sensibilização e conscientização foi a redução da violência no casal a uma questão de gênero. O paradigma de gênero, como marco explicativo da violência, carrega em si o risco de que toda violência no casal seja atrelada ao casal heterossexual e ocorrendo na direção homem-mulher, fixando-se assim, os esteriótipos de homens maltratadores e mulheres maltratadas. Esse raciocínio, não ajuda a explicar quando a violência ocorre em casais heterossexuais na direção mulherhomem (quando a mulher é a principal agressora) e tampouco a violência que ocorre em casais homossexuais.

Leonor Cantera afirma que já existem publicações e evidências suficientes para se considerar as manifestações de violência nos casais homossexuais (lésbicas e gays) e heterossexuais na direção mulher-homem, apesar dos fatores que dificultam a sua revelação e consequentemente a inexistência de dados estatísticos fidedignos. Ressalta a necessidade de se buscar teorias explicativas com um enfoque "além do gênero", pois fixar-se no paradigma de gênero dificulta a visibilidade das demais formas de violência nas relações de casal, de maneira que homens agredidos pelas esposas e casais homossexuais não têm recebido assistência social, sanitária, policial e jurídica adequadas, tampouco orientação para compreender, prevenir e controlar a violência.

Com base nessas constatações, propõe-se a buscar dados que possibilitem a análise da violência no casal (hetero/ homossexual) que abarquem e transcendam o enfoque de gênero e que permitam criar condições teóricas que dêem sustentação às intervenções práticas. Deixa claro que não se trata de buscar uma proposta anti-gênero, mas sim de lançar dúvidas sobre as certezas geradas por esse enfoque e criticar as leituras reducionistas e simplificadoras quando se pretende utilizá-lo para explicar outras formas de violência no casal.

A pesquisa de Cantera é dirigida para a busca de mitos cotidianos, que se fazem presentes no mundo social sobre as relações de casais heterossexuais e homossexuais e sobre a violência que nelas ocorrem, assim como de diferentes percepções estereotípicas de gênero, da homossexualidade e da heterossexualidade. Escolhe essa direção a fim de localizar pistas explicativas da violência em geral, dos caminhos que conduzem a ela e das vias de rompimento, como também modelos concretos e práticos que ofereçam meios de escape do entorno de violência no casal e estratégias de empoderamento das vítimas dessa violência. Fez uso de questionários contendo perguntas abertas e fechadas, respondido por 136 pessoas adultas, homens e mulheres, homo e heterossexuais e 12 entrevistas semi-estruturadas com pessoas vítimas de violência no casal.
A partir dos dados de pesquisa e de literatura pertinente, critica a imagem convencional da pessoa maltratada em relação de casal e ilustra a discussão com relatos de experiência e ação de "vítimas" que conseguiram romper efetivamente com o suposto círculo que as mantinha aprisionadas. Com base nessa discussão, levanta os comportamentos característicos da pessoa agressora e da agredida, os possíveis fatores que as mantêm unidas em uma relação de maus-tratos e aqueles que facilitam a saída do círculo de violência. Por fim, levanta elementos para um modelo de intervenção psicossocial nesse campo, apresentados através de tabelas auto-explicativas, as quais permitem a compreensão, tanto dos facilitadores de permanência e saída de numa relação de maus-tratos, assim como os indicadores de empoderamento para enfrentar a situação de violência no casal.

O livro interessa a estudantes, professores e profissionais preocupados com a questão da violência no casal, incitando o leitor a refletir numa perspectiva de desconstrução da idéia de gênero, para além dos moldes em que ela foi gestada. A linguagem utilizada é acessível e a autora ilustra muito bem as situações por meio de narrativas dos envolvidos na situação de violência. Em termos de dificuldades evidenciadas na leitura desta obra, elas se inserem, principalmente, no marco da tradução para o português, que vão além da presença de citações e depoimentos no corpo do livro, apresentados em espanhol. Isto de certa forma, afeta tanto a obra da autora, como ao leitor nas interpretações que ele possa vir a fazer.

As contribuições da obra de Cantera são inúmeras, entre elas, oferece uma extensiva revisão de literatura sobre violência no casal e ilumina um campo, antes obscurecido pela ciência, que são os maus-tratos na relação de casal homossexual e heterossexual na direção mulher-homem. Mas acima de tudo, proporciona abertura para um novo pensar e agir, humano e profissional, já que parte da crença que é possível sair de uma situação de maus-tratos e buscar o fortalecimento da "vítima", comprometendo, dessa forma, todos que compartilharam e se transformaram com a leitura.

Ana Claudia Nunes de Souza Wanderbroocke é doutoranda pelo Programa de Pós-graduação em Psicologia da Universidade Federal de Santa Catarina.

Carmen Leontina Ojeda Ocampo More é Professora Doutora Associado I do Departamento de Psicologia da Universidade Federal de Santa Catarina.
Recebido: 11/07/2009

Aceite final: 01/09/2009 